High-energy physics

\section{UK committee to push for CERN budget cuts}

BRITAIN'S spending on high-energy physics is out of balance with its spending on other science, and must be reduced substantially, according to the committee set up last year to consider continued British membership of CERN (the European Organization for Nuclear Research). The committee, chaired by molecular biologist Sir John Kendrew, will report next week to the chairmen of the Advisory Board for the Research Councils (ABRC) and the Science and Engineering Research Council (SERC) that it has been impressed with the excellence of CERN's work, but that the organization's budget should be kept constant beyond 1990 .

According to one figure being canvassed in the committee this week, the CERN budget could come down by $20-25$ per cent after 1990 without substantially affecting the quality of CERN research, which by then will depend almost entirely on the running of the large electron-positron collider LEP and its extension to "phase II" $100-\mathrm{GeV}$ operation. But whether the final report will actually mention such a figure is uncertain. Committee members are anxious to avoid a conflict with their European partners in CERN, with whom they would like to seek an agreed reduction, and to quote 20-25 per cent might be counterproductive.

Indeed, French officials last week described a cut on such a scale as "likely to kill CERN, given that half their costs are salaries". The West German position is that a 25 per cent cut "could not be done fairly". Nevertheless both countries consider that some cuts are possible. Paris considers that cuts "of a few per cent" would not harm CERN, and Bonn that a 10 per cent by 1990 might be supportable.

Sir John Kendrew and members of his committee met the West German research minister, Heinz Riesenhuber, and the French research minister Hubert Curien, earlier this year, and were encouraged to learn that others might agree that CERN budgets should be trimmed. But the committee did not visit Italy, where the government recently doubled national spending on high-energy and nuclear physics and is in a mood to increase the CERN budget rather than decrease it.

The West Germans told Sir John that the government was more comfortable with the CERN contribution than Britain because certain other projects supported by the research ministry (BMFT) (such as nuclear energy) are decreasing in cost and because, overall, the ministry has been enjoying a roughly constant real budget. $\mathrm{He}$ also argued that the expenditure on research and development in most European nations (including Britain) had decreased as a fraction of gross national product over the past decade, so effective cuts had already taken place. A German committee on big projects under Klaus Pinkau had also set a high priority for CERN and for LEP. Nevertheless Germany is looking for savings.

Mandatory scales of contribution of the eleven member states of CERN, 1985-87:

$\begin{array}{lc} & \text { Percentage } \\ \text { West Germany } & 24.90 \\ \text { France } & 20.23 \\ \text { United Kingdom } & 16.91 \\ \text { Italy } & 13.56 \\ \text { The Netherlands } & 5.39 \\ \text { Spain } & 4.94 \\ \text { Sweden } & 4.01 \\ \text { Switzerland } & 3.87 \\ \text { Belgium } & 3.61 \\ \text { Denmark } & 1.98 \\ \text { Ireland } & 0.60 \\ \text { The CERN budget in } 1985 \text { amounts to SF } 724.5 \\ \text { million (around } £ 220 \text { million). }\end{array}$

Cuts could be found, according to Riesenhuber, in reductions of staff and salaries at CERN. (One complaint is that CERN salaries are so high that it is impossible to attract German scientists back to Germany. There is also, according to Riesenhuber, scope for rationalization of CERN management and in postponing in new investments (such as extending LEP to full performance). A 10 per cent cut by 1990 is "realistic", it is believed in Bonn.

At CERN, however, the prospect of cuts is faced with some horror. CERN directorgeneral Professor Herwig Schopper would like to begin the extension of LEP to 100 $\mathrm{GeV}$ per beam as soon as technically

possible, which with rapid advances in superconducting accelerating cavities means spending sooner than expected - in 1989. This would mean a small increase in CERN spending in the new five-year planning period.

There will also be a pensions problem. Schopper says that CERN council decided four years ago to increase staff pensions in line with those available in Switzerland, which will mean increased expenditure on personnel when the main retirement bulge begins in 1990. But CERN has not yet made the investments into the pension fund either to pay for these increases or to pay the basic pension. "Our actuaries tell us there is a "technical deficit' ", says Schopper. CERN is indeed planning a reduction in personnel, and to make more use of outside contractors, but even then "it's unavoidable that there will be an increase in our personnel budget" because of the pension commitments. The only light on the horizon is that Spain will become a full member by 1989, increasing its contribution from the present 5 per cent to 7 per cent of the CERN budget, says Schopper.

For the Kendrew committee, the problem is that even a 10 per cent cut in the CERN contribution would not have provided the increased funding for other sciences that the committee believes necessary. Hence the mooted target of 20-25 per cent, and hence, no doubt, a propensity to be sceptical about Professor Schopper's claims.

Indeed, the feeling in the committee goes even further. First, an attempt should certainly be made first to reach agreement with European partners for a large reduction in the CERN budget. But if that fails, and if the hopes of some members are disappointed that collaboration with the United States will be feasible, the only option will be complete withdrawal from CERN.

Robert Walgate

\title{
Caltech at war on star wars
}

\section{Washington}

MARVIN Goldberger, president of California Institute of Technology, has written to Secretary of Defense Caspar Weinberger taking exception to an announcement that Caltech had joined a "consortium" of universities carrying out star wars research. In his letter, Goldberger says that Caltech's only involvement in the $\$ 9$ million contract announced by the Innovative Science and Technology (IST) division of the Strategic Defense Initiative organization for research on optical signal processing is a single $\$ \mathbf{\$ 5 0 , 0 0 0}$ subcontract to one Caltech scientist from the University of Dayton Research Institute.

A press release put out by the IST office announced the "formation of a consortium of several institutes," including Carnegie Mellon, Stanford and Massachusetts Institute of Technology.
Caltech has yet to approve the contract. Both Caltech and Stanford have also expressed concern about news reports that the work would be classified. But according to Dr James Ionson, who heads the IST office, all the work would be totally free of classification or other restrictions in accordance with Department of Defense policy on basic research that is conducted on campus.

lonson defended the use of the term "consortium", saying that the scientists involved had worked together on the proposal, which was submitted by the University of Dayton and the University of Alabama at Huntsville. "The important news is that some of the most prestigious individual scientists are working together for a common goal", he said. As to Goldberger, "It's no secret that he's not an advocate of SDI." Stephen Budiansky 